\title{
Sea surface temperature and torrential rains in the Valencia region: modelling the role of recharge areas
}

\author{
F. Pastor ${ }^{1}$, J. A. Valiente ${ }^{1}$, and M. J. Estrela ${ }^{2}$ \\ ${ }^{1}$ Instituto Universitario Centro de Estudios Ambientales del Mediterráneo CEAM-UMH, Paterna, Valencia, Spain \\ ${ }^{2}$ Faculty of Geography and History, University of Valencia, Valencia, Spain \\ Correspondence to: F. Pastor (paco@ ceam.es)
}

Received: 17 December 2014 - Published in Nat. Hazards Earth Syst. Sci. Discuss.: 12 February 2015

Revised: 3 July 2015 - Accepted: 23 July 2015 - Published: 31 July 2015

\begin{abstract}
Heavy rain events are frequently recorded in the Western Mediterranean causing economic losses and even human casualties. The Western Mediterranean is a deep and almost closed sea surrounded by high mountain ranges and with little exchange of water with the Atlantic ocean. A main factor in the development of torrential rains is oceanatmosphere exchanges of heat and moisture that can potentially destabilize air masses travelling over the sea. The study of air mass trajectories previous to the rain event permits the identification of sea areas that could probably contribute to the development or intensification of rainfall. From a previous Mediterranean sea surface temperature climatology, its spatio-temporal distribution patterns have been studied showing two main distribution modes in winter and summer and transitional regimes in spring and autumn. Hence, three heavy precipitation events, for such winter and summer sea temperature regimes and for fall transition, affecting the Valencia region have been selected to study the effect of sea surface temperature in torrential rains. Simulations with perturbed sea surface temperature in different areas along the air mass path were run to compare results with unperturbed simulation. The variation of sea surface temperature in certain areas caused significant changes in model accumulated values and its spatial distribution. Therefore, the existence of areas that at a greater extent favour air-sea interaction leading to the development of torrential rainfall in the Valencia region has been shown. This methodology could be extended to the whole Mediterranean basin to look for such potential recharge areas. The identification of sea areas that contribute to the development or intensification of heavy rain events in the Mediterranean countries could be a useful prognosis and/or monitoring tool.
\end{abstract}

\section{Introduction}

The particular configuration of the Western Mediterranean area, an almost closed sea surrounded by high mountain ranges and with little water-mass exchange with other seas, determines its own meteorological (Jansà et al., 2000; Millán et al., 2005b, a; Palau and Rovira, 2014) and oceanic (Bethoux et al., 1999; Robinson et al., 2001) dynamics and behaviour. A remarkable feature of the Mediterranean climatology is the torrentiality of its precipitation regime. This torrentiality leads to relatively frequent floods, floods being an important meteorological risk in Europe (Barredo, 2009; EEA, 2010) and, not so frequently, Northern Africa, causing high economic losses and sometimes human casualties.

Heavy rains and flash floods are frequently recorded and well documented in the Western Mediterranean basin, as in the MEDEX (Jansa et al., 2014) and CIRCE (Navarra and Tubiana, 2013) projects, and in the Valencia region (Estrela et al., 2013; Millán et al., 2005b; Peñarrocha et al., 2002). These rain events have been studied from different points of view, running from a statistical relationship between cyclones and heavy rain (Jansà et al., 2001) and climatology of cyclones causing floods or torrential rains (Lionello et al., 2005; Homar et al., 2007; Campins et al., 2011; Kouroutzoglou et al., 2011) to numerical modelling of heavy rain events (Romero, 2001; Martín et al., 2007; Ducrocq et al., 2008; Bresson et al., 2009; Pastor et al., 2010; Cohuet et al., 2011; Duffourg and Ducrocq, 2011; Gómez et al., 2011), in order to investigate their distribution, future trends and the mechanisms involved in their development. 
Regarding the effect of sea surface temperature (SST) on torrential rains, different studies have been made in different areas of the Mediterranean, ranging from a climatological relationship (Pastor et al., 2008) to the numerical study of different events (Lebeaupin et al., 2006; Bozkurt and Sen, 2009; Katsafados et al., 2011; Miglietta et al., 2011). For the Valencia region, evidence of the influence of SST in torrential rains in the area have been found by means of studying satelliteretrieved SST before and after rain events (Millán et al., 1995), running numerical simulations with perturbed SST fields (Fernández et al., 1997; Romero et al., 2014) or using different SST data sets as model initial conditions (Pastor et al., 2001) for single events. Other authors have also investigated a possible climatic relationship between global SST anomalies in the Western Mediterranean and precipitation events in the Spanish Mediterranean coast (García Codron et al., 2004). Hence, SST has been shown as a key, but not the only, factor in the development and/or intensification of torrential rains in the Valencia region. Although studies in other Mediterranean areas show differences in the importance of SST in both annual precipitation and torrential rain events, Katsafados et al. (2011) state that SST variation, coming from different sources, does not significantly affect the simulation of a deep cyclone in the Eastern Mediterranean. Miglietta et al. (2011) found that SST variations could weaken a Mediterranean cyclone and Tous et al. (2013) showed the important role of surface heat fluxes in the development of medicines. Lebeaupin et al. (2006) found that a higher SST increases surface heat fluxes, moistens and destabilizes air mass leading to stronger convection and higher precipitation totals; Bozkurt and Sen (2009) state that increased SST enhances precipitation in the Anatolia peninsula for both annual climatology and extreme events. Results from summarizing cited authors leads to the idea that SST is a factor that, in the presence of favourable synoptic conditions (Lenderink et al., 2008), can enhance and/or increase precipitation by helping in the addition of heat and moisture to the air mass while it does not generate torrential precipitation events all alone.

As SST was shown as a key factor in the intensity of torrential rains in the Valencia region (Millán et al., 1995; Pastor et al., 2001) the authors wanted to further investigate the Mediterranean areas that most influenced rain events in our region. The heat/moisture exchange between the sea and the air mass travelling across a warmer Mediterranean has been studied from an observational (Estrela et al., 2003) and modelling (Tous et al., 2013) perspective. Those surface fluxes can potentially destabilize the air mass by deepening/intensifying convection (Moscatello et al., 2008); this has also been recently investigated in the HyMeX project by Rainaud et al. (2015) by the comparison of observations and model results. They found that, although heavy precipitation events were observed without significant air-sea fluxes, the large air-sea flux values simulated were generally correlated with the torrential rain events, being of interest for us the fact that large air-sea exchanges on the Balearics-Iberian Penin- sula basin are generally associated with heavy rain events over eastern Spain.

Depending on the air mass trajectory prior to the rain event, air-sea interaction could be more or less intense because of the temperature difference between sea surface and the atmosphere and due to the time in which exchanges can develop. If such recharge areas, understood as areas of important or intense heat/moisture air-sea exchanges, could be identified, that information might be useful for the forecasting and monitoring of heavy rains.

In previous works by Pastor (2012) an SST climatology was built for the Mediterranean from satellite data. In that work, SST monthly spatial distribution was studied for the period 1982-2009. The main results showed the existence of two different spatial distribution modes in winter and summer with transitional periods in spring and autumn. At the same time, differentiated SST areas were identified by means of clustering techniques. Hence, the relationship between SST values in these areas and torrential rains could be studied. The objective of this work is to determine the contribution of the sea surface temperature (SST) to the development/intensification of torrential rain events in the Valencia region. For the accomplishment of this objective, a new strategy has been tried in our simulation experiments to assess the role of SST in the Valencia region, which we think could be exported to other Mediterranean regions. Instead of arbitrarily perturb SST field (usually made by adding or subtracting a constant value) close to the rain area or in the whole simulation domain, we have tried to determine SST regions that may play a role in the development of the torrential rain and then to investigate just the effect of that specific area in the model results.

Consequently, this work consists of two main parts; the first part outlines the work by Pastor (2012) to briefly introduce the spatio-temporal structure of SST in the Mediterranean while in the second one numerical model simulations are run to analyze the influence of SST on the precipitation model results. The latter part of this paper is structured in three sections; first one, data and methodology, describes SST data set used and RAMS meteorological model and then explains the methodology followed in the simulation experiments. Numerical modelling section presents and discusses the results of the different simulation experiments. Finally, conclusions constitute the last section of the paper.

\section{Data and methodology}

\subsection{Sea surface temperature data}

Pastor (2012) studied sea surface temperature in the Mediterranean for a 28-year long period, ranging from 1982 to 2009. SST data used for that study were obtained from the NASA/NOAA Pathfinder data bases. The Pathfinder project is dedicated to the production of global SST maps from 1982 
to the present day with data measured by the AVHRR sensors aboard the NOAA satellites. AVHRR Pathfinder Version 5.0 data are available at a global scale and at $4 \mathrm{~km}$ spatial resolution, and they are obtained twice daily for daytime and night-time satellite passes. This SST data set was validated for its use in the Mediterranean by D'Ortenzio et al. (2000). Marullo et al. (2007) determined that Pathfinder data were a consistent data set that could be used in the detection of trends and SST variability. More information on Pathfinder SST data is available at Kilpatrick et al. (2001) and on the data set website ${ }^{1}$.

A monthly climatology for the period January 1982 to December 2009 was built in Pastor (2012) to study SST in the Mediterranean. Mean monthly values were calculated from daily data in every grid point covering the Mediterranean, with the restriction of having at least $75 \%$ of valid daily values, preferably night-time values but using daytime ones if they were not available. Additionally, clustering techniques were used to study SST spatial distribution patterns across the whole study period for monthly values and anomalies. From a temporal analysis two distinct, well-defined SST regimes were found for summer and winter with two transitional periods in spring and autumn. Usually, the spring transition from the winter to the summer regime is more abrupt and shorter in time than the autumn transition. The spring transition period lasts between 1 or 2 months in April and May, although in some years April shows more resemblance to the winter than to the summer regime. The autumn transition lasts longer, from 2 to 3 months, i.e. September to November, and runs more smoothly. It should be noted, to avoid confusion, that seasonal nomenclature for temperature regimes does not strictly coincide with the climatological seasons. In some cases climatic season and SST regime can be shifted so we can find a summer SST regime during climatological fall or even early winter.

From the clustering analysis on spatial SST distribution two main modes of areal distribution for winter and summer respectively, and two transitional periods in spring and autumn were found (Fig. 1). For the winter mode a clear positive north-to-south gradient (Fig. 1a) was found for the whole Mediterranean with higher SST values in the southernmost part of the Eastern Mediterranean basin. The winter mode usually starts in late November and lasts until March, although in some years April retains some structure similar to winter months. After the spring transitional period (Fig. 1b), usually April and May, the summer mode (Fig. 1c) presents a completely different structure characterized by the presence of clearly distinct areas. The coldest areas in summer are the Alboran Sea, Gulf of Lion and the Aegean, especially its eastern part. Higher SST values are found in distant areas like the one between the central coast of the Iberian Peninsula (IP) and the Balearic sea, the Thyrrenian and Ionian seas and the area from the south of Crete to the Egyptian coast.

${ }^{1}$ http://www.nodc.noaa.gov/SatelliteData/pathfinder4km/
The highest temperatures are found on the Gulf of Libya and in another area running from southern Turkey and Cyprus to the coast of the Middle East. This distribution can be conditioned by oceanic circulation and, at least in part, by meteorological causes: for example, the Gulf of Lyon and Aegean sea areas are affected by strong and persistent wind regimes, Mistral and Etesian winds respectively. The rest of the Western Mediterranean (WMED) basin wind regime in summer is dominated by breeze cycles and vertical air mass recirculation (Millán et al., 2005b; Palau and Rovira, 2014) over the basin which may be the drivers of the clusters in the Valencia region-Balearic Islands area and in the Thyrrenian sea. In the Eastern Mediterranean basin (Kallos et al., 1998), the Gulf of Libya and Middle East are areas where breeze cycles develop in summer. The prevailing light surface winds can favour the stagnation, or weak displacement, of surface waters, an exception is made of the Aegean sea where the Etesian (N-NE) winds are predominant in summer. The autumn transitional period (Fig. 1d) usually starts in October, although in some years it can comprise part of September, and it is not as steep as the spring transitional mode, usually ending in November and leading to the winter regime in December.

\subsection{RAMS model: description and configuration}

Regional Atmospheric Modelling System (RAMS) (Pielke et al., 1992) has been used in previous work at Fundación CEAM in the study of Mediterranean meteorology and pollutant dispersion from versions $4 . \mathrm{x}$ up to the most recent 6.0 version, the one used to run simulations shown in this paper. RAMS optimum configuration for mesometeorological studies in the Valencia region was investigated by Salvador et al. (1999). RAMS has also been used to study the effect of sea surface temperature on torrential rains (Pastor et al., 2001), air pollution dispersion (Palau et al., 2005; Pérez-Landa et al., 2007a, b) and on the implementation of a heatwave alert system in the Valencia region (Gómez et al., 2014). RAMS has also been used in the study of heavy rains and floods in the Mediterranean area by other authors like Meneguzzo et al. (2004), Federico et al. (2008), Pastor et al. (2010) and Gómez et al. (2011).

The initial and boundary atmospheric conditions used for the simulations in this paper come from the National Centre for Environmental Prediction (NCEP) reanalysis, obtained from the National Center for Atmospheric Research (NCAR) (Kalnay and Coauthors, 1996). Reanalysis data are available every $6 \mathrm{~h}$ at $2.5^{\circ} \times 2.5^{\circ}$ resolution and 17 pressure levels. These data are used in a four-dimensional data assimilation scheme to define forcing at the lateral boundaries of the outermost five grid cells of the largest simulation domain. For the surface boundary conditions we have used land cover data sets from the US Geological Survey (Anderson et al., 1976). SST initial data for the simulation was obtained for the model domain from the NASA/NOAA Pathfinder data bases. 

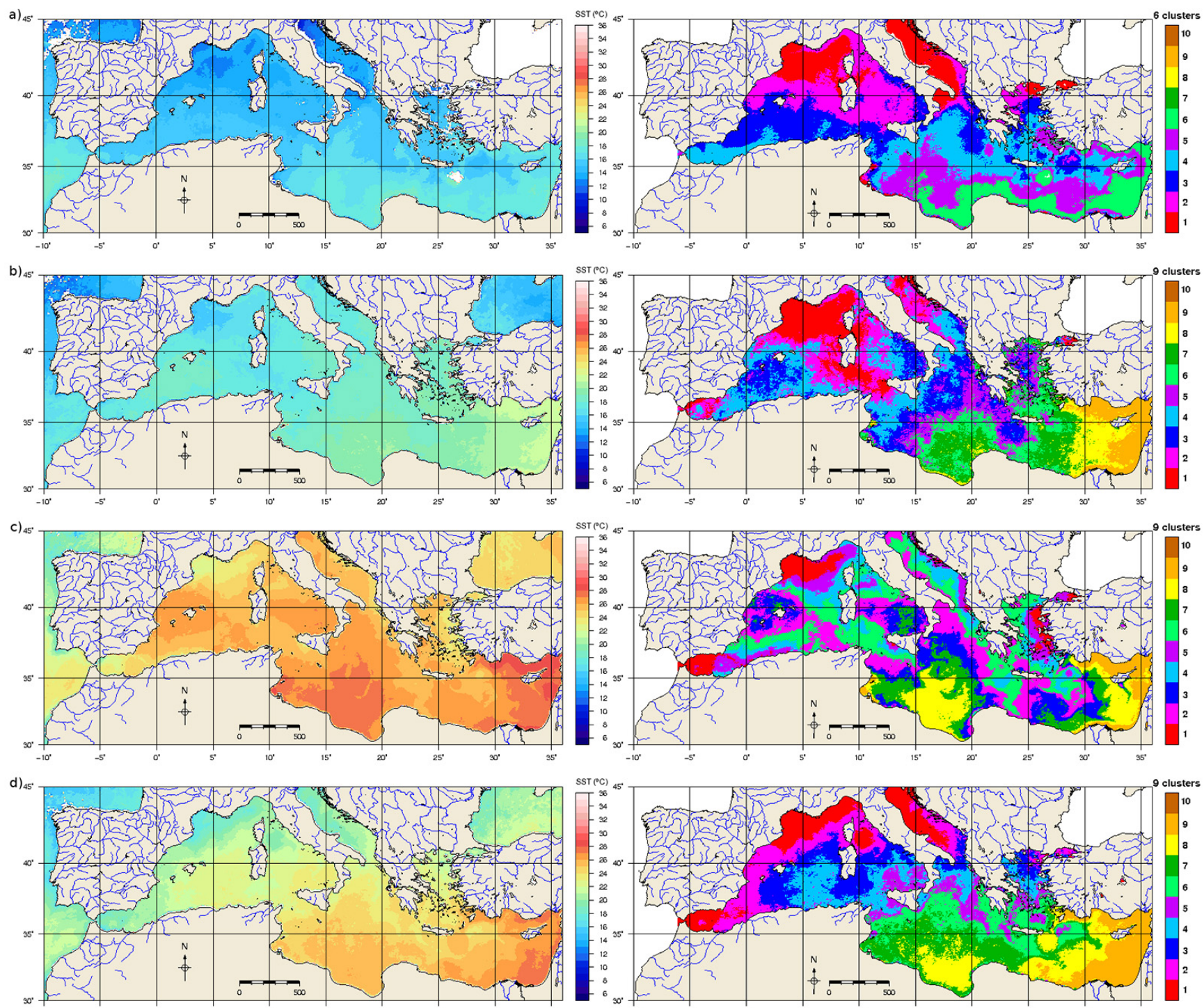

Figure 1. Mean SST value (left column panels, ${ }^{\circ} \mathrm{C}$ ) and clustering (right column panels) for (a) winter, (b) spring, (c) summer and (d) autumn SST regimes (from Pastor, 2012), showing latitudinal SST gradient in winter and discrete area patterns in summer along with two transitional regimes in spring and autumn. Same cluster index on different season do not stand for same SST values.

RAMS own soil-vegetation surface scheme (LEAF-3) is applied to evaluate sensible and latent heat flux exchanges with the atmosphere, using prognostic equations for temperature and soil moisture. LEAF-3 has been prescribed with a homogeneous soil texture of the clay-loam type. Soil column holds 11 layers down to a depth of $2 \mathrm{~m}$ with moisture initialized with a uniform profile at a value of $0.38 \mathrm{~m}^{3}$ of water per cubic metre of total volume. The initial soil temperature profile is obtained by subtracting $2.3^{\circ} \mathrm{C}$ from the surface air temperature in the top soil layer. Temperature linearly decreases by $1^{\circ} \mathrm{C}$ in the bottom soil (Pérez-Landa et al., 2007b).

Simulation runs in this paper have been designed with four domains of decreasing size at increasing spatial resolution. Four, two-way interactive, nested domains have been used whose horizontal resolution is shown in Table 1. All four grids hold 45 vertical levels, starting from a $30 \mathrm{~m}$ thick level near the surface that gradually increases to a maximum of $1000 \mathrm{~m}$ thickness near the model top, located at about $17000 \mathrm{~m}$. The cloud and precipitation microphysics scheme (Walko et al., 1995) has been applied in all the domains. From the work of Gómez et al. (2011) the Kuo convective parameterization scheme has been activated in RAMS model for the three outer grids as it showed the best results in the modelling of torrential rain events. For model grid $4(1.5 \mathrm{~km}$ horizontal resolution) no convective parameterization is activated so that the model is left free to generate its own smallscale features and convective precipitation. 
Table 1. Rams model settings.

\begin{tabular}{lrrrrr}
\hline Grid & $n x^{\mathrm{a}}$ & $n y^{\mathrm{a}}$ & $n z^{\mathrm{a}}$ & \multicolumn{1}{c}{$\Delta X^{\mathrm{b}}$} & Time $^{\mathrm{c}}$ \\
\hline 1 & 90 & 80 & 45 & 40500 & 60 \\
2 & 110 & 101 & 45 & 13500 & 30 \\
3 & 83 & 101 & 45 & 4500 & 15 \\
4 & 128 & 101 & 45 & 1500 & 5 \\
\hline
\end{tabular}

a number of grid points; ${ }^{b}$ cell size in metres; ${ }^{c}$ model timestep in seconds.

\subsection{Numerical modelling methodology}

To achieve the objective of this work, to determine SST contribution to the development/intensification of torrential rains in the Valencia region, we have employed a new approach for our simulation experiments with RAMS model. As a first step, we have studied the air mass trajectories leading to the rain event in order to determine the Mediterranean areas that can act as moisture/heat sources for that specific rainfall episode. Air mass backward trajectories in the days previous to the event have been computed with the HYSPLIT model available online on the NOAA Air Resources Laboratory website ${ }^{2}$, fed with NCEP/NCAR Reanalysis. First, a numerical simulation is run for each studied event with SST original/unperturbed data so it can be used as a control simulation. Then, new RAMS simulations are run with perturbed SST for the different areas located along the air path. Thus, in principle, the difference between control and perturbed simulations should only come from the different initialization of the SST field. In most cases, simulation results will be affected by SST from different areas in the Mediterranean so we should perform a control simulation with unperturbed monthly SST plus $m$ simulations, $m$ being the number of sea areas across the air mass trajectory for each rain event, with area prescribed/perturbed SST. Additionally we ran another simulation for all events in which SST is perturbed for all areas in the air mass path. For all these simulations, perturbation of SST consists in prescribing a $10^{\circ} \mathrm{C}$ constant value for the whole area in order to minimize air-sea exchanges while the air mass travels across the area. In this sense, Miglietta et al. (2011) stated that numerical experiments with colder SST values lowered the intensity of the sea-surface fluxes and reduced convection development in the case of a Mediterranean cyclone. More recently, Romero et al. (2014) have also studied the sensitivity of a severe convective storm to SST field modification and found that SST cooling can dramatically affect convection by affecting surface fluxes and air-sea exchanges while warmer SST enhances and intensifies convection processes.

\footnotetext{
${ }^{2}$ Rolph, G. D.: Real-time Environmental Applications and Display sYstem (READY) Website http://www.ready.noaa.gov, NOAA Air Resources Laboratory, College Park, MD.
}

Table 2. Set of simulation experiments.

\begin{tabular}{|c|c|c|c|}
\hline Event & Control & $\begin{array}{l}\text { Simulations with } \\
\text { perturbed SST }\end{array}$ & $\begin{array}{l}\text { SST distribution } \\
\text { type }\end{array}$ \\
\hline September 1989 & CtrlA & $\mathrm{A} 1, \mathrm{~A} 2, \mathrm{~A} 3, \mathrm{~A} 0$ & \\
\hline October 2000 & CtrlB & $\mathrm{B} 1, \mathrm{~B} 2, \mathrm{~B} 3, \mathrm{~B} 0$ & Transitional autumn \\
\hline October 2007 & CtrlC & $\mathrm{C} 1, \mathrm{C} 2, \mathrm{C} 0$ & Winter \\
\hline
\end{tabular}

Perturbation of SST sets all values in area to $10^{\circ} \mathrm{C}$.

\section{Numerical modelling results}

In this work we have chosen three torrential rain events with intense and persistent precipitation provoking important floods in the Valencia region. The selected events occurred in late summer or autumn, when most of the floods and heavy rain episodes are registered in our region (Peñarrocha et al., 2002), for September 1989, October 2000 and October 2007. These rain events correspond to the summer and winter SST modes and to the transitional autumn regime (Table 2).

These rain episodes share some synoptic features that are present in a great number of the intense rain events in the Valencia region (Peñarrocha et al., 2002). In the three cases we found an easterly flow, ranging from northeast to southeast, both at surface and middle levels feeding moisture from the Mediterranean to the synoptic or mesoscale rain-producing systems. At upper levels we found the presence of cold unstable air over or close to the Valencia region, in the form of a cold trough over eastern IP for the October 2000 event or a cold pool over southwestern IP in the other two cases with its easternmost part close to eastern IP. This synoptic situation with instability at upper levels and marine moisture feeding to the Valencian orography, acting as trigger mechanism, led to persistent and intense rains for the three events and appeared in many important rain episodes in the Valencia region. Table 2 shows simulation experiments run for this paper. In the following subsections, numerical modelling results for the three rain events are analysed. Although in this work we do not intend to evaluate the accuracy of the modelling results (for more detailed model evaluation see Pastor et al., 2001, 2010), we have to note that, in general terms, RAMS control simulations reproduce fairly well spatial distribution of precipitation but fails in reproducing accumulated values, especially by underestimating maximum values. An observed precipitation map for each event is available as Supplement to aid for a comprehensive evaluation of model results.

\subsection{September 1989 event}

From 4 to 7 September heavy rains were recorded in the Valencia region, mostly in its southern-central areas. Accumulated precipitation values reached $500 \mathrm{~mm}$ during the whole event in some stations, with daily values greater than $200 \mathrm{~mm}$ (Pastor et al., 2001). This rain event was characterized at surface levels by the presence of a high pressure anticy- 

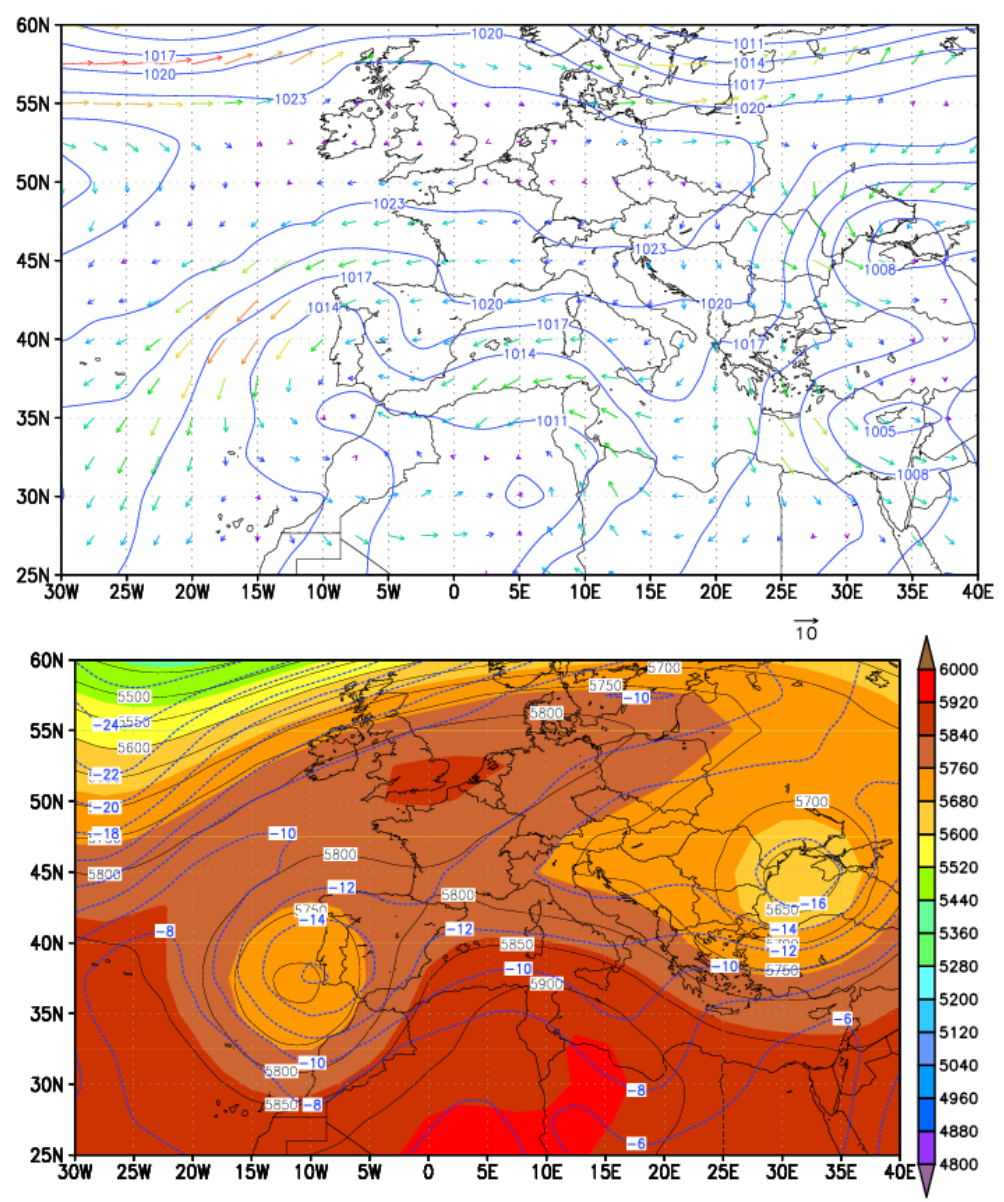

Figure 2. Synoptic situation on 7 September 1989, 00:00 UTC; (a) sea surface pressure and winds at surface level; (b) geopotential height (gpm) and temperature at $500 \mathrm{hPa}$. Plotted from NCEP model data.

clonic area over central Europe and relatively low pressures over Northern Africa (Fig. 2a), driving the air mass along an easterly/northeasterly flow over the Mediterranean (Fig. 3a), while at upper levels (Fig. 2b) a cold air pool was located over IP.

Figure 4 shows SST fields used in the different simulations of the September 1989 rain event, corresponding to a summer SST spatial distribution, according to the work of Pastor (2012) shown in Fig. 1. As the rain event occurred during the first week of the month, monthly August data for SST have been used. Upper left map shows SST for the control run, original Pathfinder SST data while the rest of maps show the perturbed SST field, prescribing a value of $10^{\circ} \mathrm{C}$ for the different simulations in Table 1.

Simulations for this event, with a duration of $120 \mathrm{~h}$, begin on 3 September at 00:00 UTC and end at 00:00 UTC on 8 September. RAMS model accumulated precipitation total for the whole set of simulations is shown in Fig. 5. Control simulation (CtrlA) for the September 1989 event shows a wide precipitation area with amounts higher than $100 \mathrm{~mm}$ where two areas with maximum precipitation can be distin- guished. The northernmost, and smaller, area reaches accumulated values of $400 \mathrm{~mm}$ while the greater one surpasses $600 \mathrm{~mm}$, mostly standing over the sea. From these results, most of the precipitation, and also the highest values, occurred over the sea and coastal areas.

In the A1 simulation (Fig. $5 b$ ) significant changes were observed with respect to the control simulation. The $100 \mathrm{~mm}$ area is now greater over land than in the control simulation but the most noticeable difference is the displacement of the maximum precipitation area some distance inland, although not far from the coast, with values higher than $500 \mathrm{~mm}$. In this case, the maximum simulated precipitation is located over land on coastal areas and rapidly decreases when going offshore, contrary to the control simulation. A dramatic precipitation decrease appears in A2 (Fig. 5c) simulation with respect to the control one, with precipitation under $100 \mathrm{~mm}$ over the whole simulation area and its maximum located far to the south from the control simulation peak. For A3 experiment (Fig. 5d) the model shows a rainfall spatial distribution that resembles that of the control simulation but with lower values across the whole modelling area. Again, the precip- 

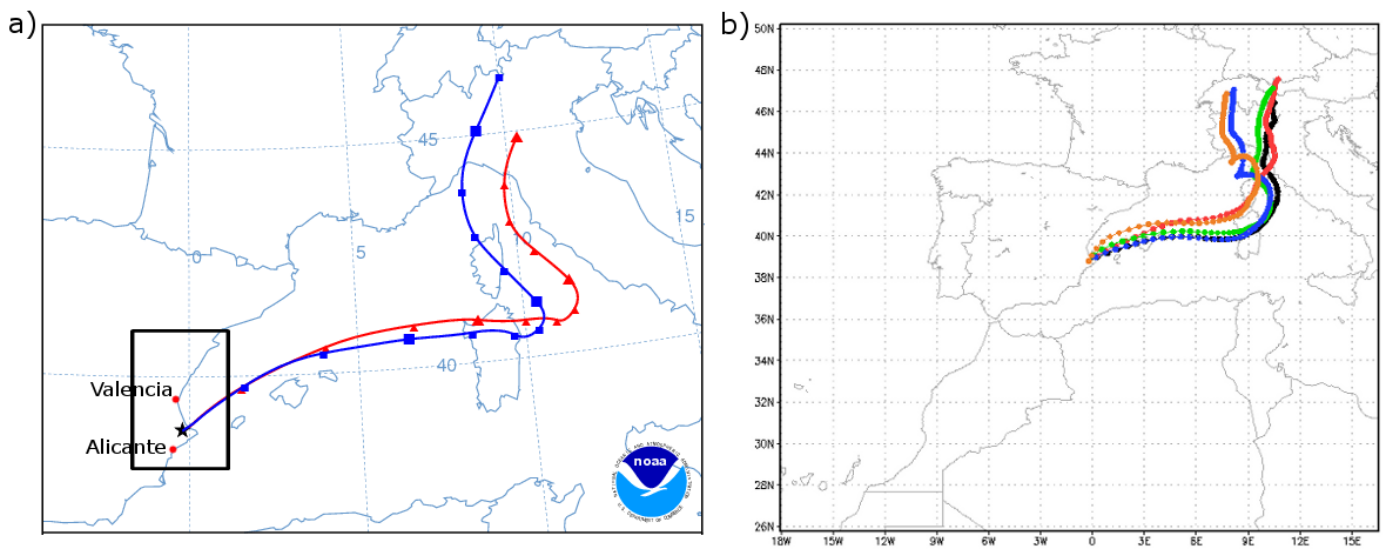

Figure 3. Backward trajectories ending in the rain area $\left(38.8^{\circ} \mathrm{N}, 0.2^{\circ} \mathrm{W}\right.$ ) for the September 1989 event. (a) $72 \mathrm{~h}$ trajectories (source: NOAA Air Resources Laboratory) ending at $100 \mathrm{~m}$ a.g.l. (above ground level) at 18:00 UTC, 6 September (blue) and 00:00 UTC, 7 September (red), (b) trajectories ending at 00:00 UTC, 7 September (source: RAMS model, CtrlA: black, A1: red, A2: green, A3: blue, A0: orange). Black box encompasses Valencia region, including Valencia (VAL) and Alicante (ALI) location.

itation maximum extends across the coastal areas and over the sea but with a more confined spatial extent than in the control simulation, especially to the north of the simulation area where a maximum precipitation area from the control simulation is not present in this case. Finally, A0 experiment (Fig. 5e) shows similar results to those from A2 simulation but with still lower values and almost without precipitation over land except from a reduced area over the coast.

It is remarkable that $\mathrm{A} 1$ simulation modifies precipitation field and increases its values, especially the higher ones, with respect to control simulation while the rest of the simulations clearly decrease precipitation values and its spatial extent. The analysis of vertical cross sections of equivalent potential temperature and vertical velocity (see Supplement) present some differences between the analyzed simulations. For control A1 and A3 simulations, a moist surface air flux towards the Valencian coast is found (see RAMS model trajectories in Fig. 3), with higher moisture content for the CtrlA and slightly decreasing values for $\mathrm{A} 1$ and $\mathrm{A} 3$, while $\mathrm{A} 2$ and $\mathrm{A} 0$ surface fluxes present lower moisture contents than in the rest of the experiments. A notable difference comes for the vertical velocity field with strong vertical circulation present on CtrlA and A1 simulations being weak in the rest of experiments. In the case of the control simulation this vertical ascent is present just off the coast while in A1 it is displaced some distance inland, and probably enhanced by orographic lifting. These changes could explain the displacement of the maximum precipitation area from its offshore location on CtrlA to the new location over land on A1.

It is also noticeable that RAMS computed trajectories (Fig. 3b) for all the simulations are quite similar, and also similar to the ones computed from reanalysis data, concluding that no significant changes arise in atmosphere dynamics for the different experiments.

\subsection{October 2000 event}

A long-lasting rain episode took place in the Valencia region between 22 and 26 October 2000. Rainfall also had a large spatial extent, affecting most of the Valencia region, with daily accumulated values greater than $300 \mathrm{~mm}$ in a noticeable number of stations with total episode accumulation over $500 \mathrm{~mm}$ (see Supplement). Regarding synoptic conditions (Fig. 6), a cold trough at upper levels extended across western IP until an isolated cold air pool formed over Southwest IP and Northwest Africa on 22 October. For this event, a long east to southeasterly air flow travelled across the whole Western Mediterranean basin (Figs. 6 and 7a) heading towards the eastern coast of the IP. In the trajectories computed from simulation experiments (Fig. 7b), the cases with perturbed SST field move slightly to the north with respect to the control simulation in the area between Sicily and the coast of Libya to converge again near the Balearic Islands. Sea surface temperature field (Fig. 8) for this event showed a transitional autumn distribution (see Fig. 1d). A more comprehensive description of the event can be found in Homar et al. (2002).

In this case simulations ran for $120 \mathrm{~h}$, starting on $21 \mathrm{Oc}-$ tober at 00:00 UTC and ending at 00:00 UTC on 26 October; model precipitation total is shown in Fig. 9. The precipitation event recorded in October 2000 (see Supplement) affected a wide area to the centre and north of the Valencia region; RAMS model accumulated precipitation results for the control simulation, CtrlB (Fig. 9a), show relatively good agreement with recorded precipitation regarding spatial distribution but fails in the maximum rainfall values. Model results show a large rain band extending parallel to the coast, but some distance inland, with values higher than $100 \mathrm{~mm}$ inland and weak precipitation over the sea. Regarding maximum values, some reduced areas over $200 \mathrm{~mm}$ are found 

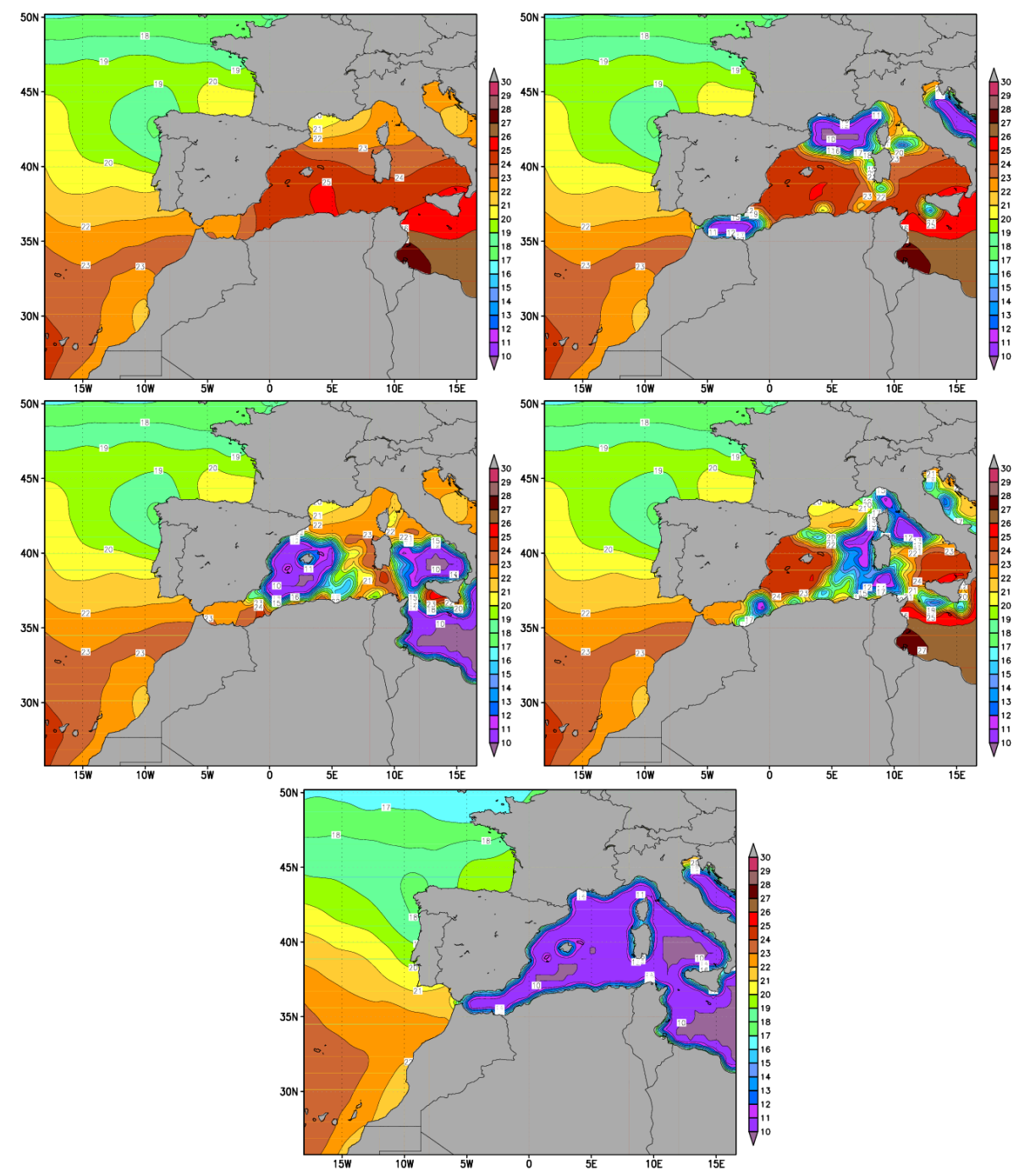

Figure 4. RAMS model SST fields for the simulation of September 1989 event (August monthly data): (a) control run, (b) A1 simulation, (c) A2, (d) A3 and (e) A0. Perturbations of SST field obtained by prescribing a constant $10{ }^{\circ} \mathrm{C}$ in the desired areas (violet).

and a maximum accumulated precipitation over $300 \mathrm{~mm}$ is located to the north of the modelled area. In the first simulation with perturbed SST field B1 (Fig. 9b), RAMS model shows similar results to those in control simulation but with slightly higher values over land. A greater precipitation area, with values over $100 \mathrm{~mm}$, than in control run is found over land to the south of the model grid while similar or slightly higher values are found on the rest of the rain areas.

The rest of the simulations for this event (B2, B3, B0) show similar results regarding spatial rainfall distribution while they differ in the amounts of precipitation calculated by the model. B2 simulation (Fig. 9c) shows a remarkable shift towards the coast line for simulated rainfall where a rain band over $100 \mathrm{~mm}$ is found. Precipitation inland, in the western half of the model grid, is clearly lower than in control simulation, more remarkably for the maximum areas. The third simulation for the October 2000 event, B3 (Fig. 9d), shows the same spatial structure for precipitation seen in B2 run with a rain band along the coast but with generally higher precipitation values than in B2 case. Finally, B0 simulation results (Fig. 9e) are fairly similar to those in B2 in spatial distribution just showing slightly lower accumulated precipitation values.

Summarizing the model results, B1 simulation shows similar results to the control simulation for precipitation spatial distribution but with some changes for accumulated rainfall while the rest of the numerical experiments shift precipitation rain band to the east just over the coast line. Regarding modelled precipitation, B2, B3 and $\mathrm{B} 0$ differ in accumulated value, $\mathrm{B} 0$ being the one with lower values and $\mathrm{B} 3$ the one with the highest ones. It is remarkable that B0 simulation gives very similar precipitation values as in $\mathrm{B} 2$.

Regarding Mediterranean moisture fluxes, RAMS model trajectories in Fig. 7b show the long-range marine advection 


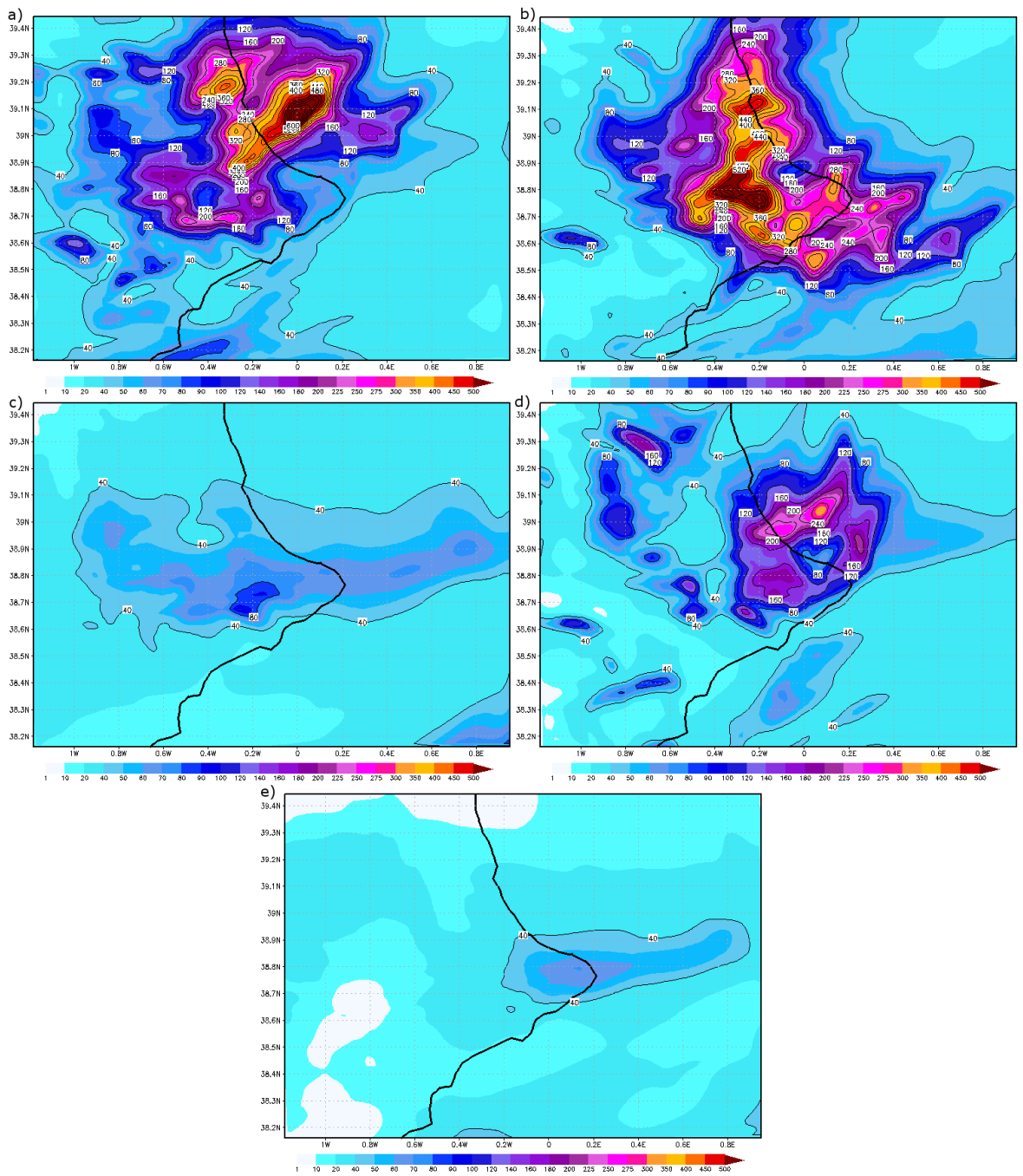

Figure 5. RAMS model accumulated precipitation (mm) for September 1989 event for (a) CtrlA simulation, (b) A1, (c) A2, (d) A3 and (e) A0.

towards the Valencia coast. In this event, control and B1 simulations show similar equivalent potential fields (see Supplement) in a cross vertical section at the latitude of the rain area. In the rest of the simulations, B3, B2 and B0 moisture flux is clearly weaker than in the first ones. For these latter modelling experiments, a decrease in equivalent potential temperature (see Supplement) is found over the coastal rain areas with respect to the $\mathrm{CtrlB}$ and $\mathrm{B} 1$ simulations.

\subsection{October 2007 event}

The October 2007 rain event is the shortest of the three episodes studied in this paper. Rain started on the second half of 11 October and lasted for about 16 to $20 \mathrm{~h}$ depending on the location. In addition to its shorter duration, the rain had a high spatial concentration and intensity, focusing on the coastal area to the south of the Valencia and northern
Alicante provinces. Records over $300 \mathrm{~mm}$ were obtained in this area with a few points over $400 \mathrm{~mm}$ (Pastor et al., 2010).

Similar to the other two events, strong instability was present at upper levels with a cold trough arriving to the IP between 9 and 10 October. Finally, the trough evolved to an isolated cold pool which was located in the vertical of the Valencia region on 11 and 12 October (Fig. 10). At surface levels a northeasterly wind flow (Fig. 11a) advected a humid air mass across the northwestern Mediterranean towards the Valencia region; it can be seen (Fig. 11b) that for the perturbed SST simulations the path of the air mass over the sea is longer than in control simulation but is still travelling over the same areas of the Mediterranean. This wind flux was driven across the southern edge of a strong anticyclone located over France and southern England, with high pressures extending across central Europe. Figure 12 shows SST distribution for this event, corresponding to winter mode. 

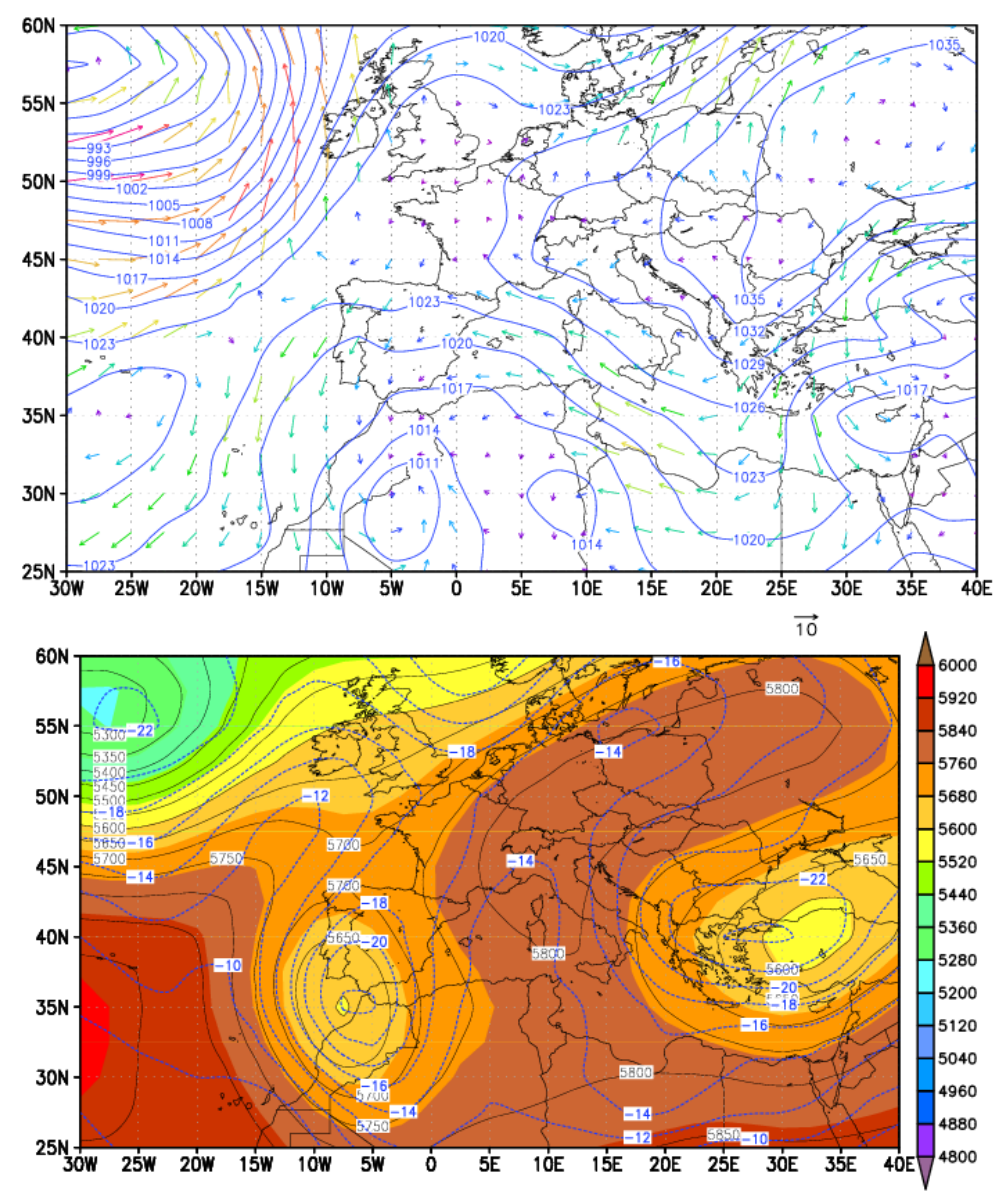

Figure 6. Synoptic situation on 22 October 2000, 00:00 UTC; (a) sea surface pressure and winds at surface level; (b) geopotential height (gpm) and temperature at $500 \mathrm{hPa}$. Plotted from NCEP model data.
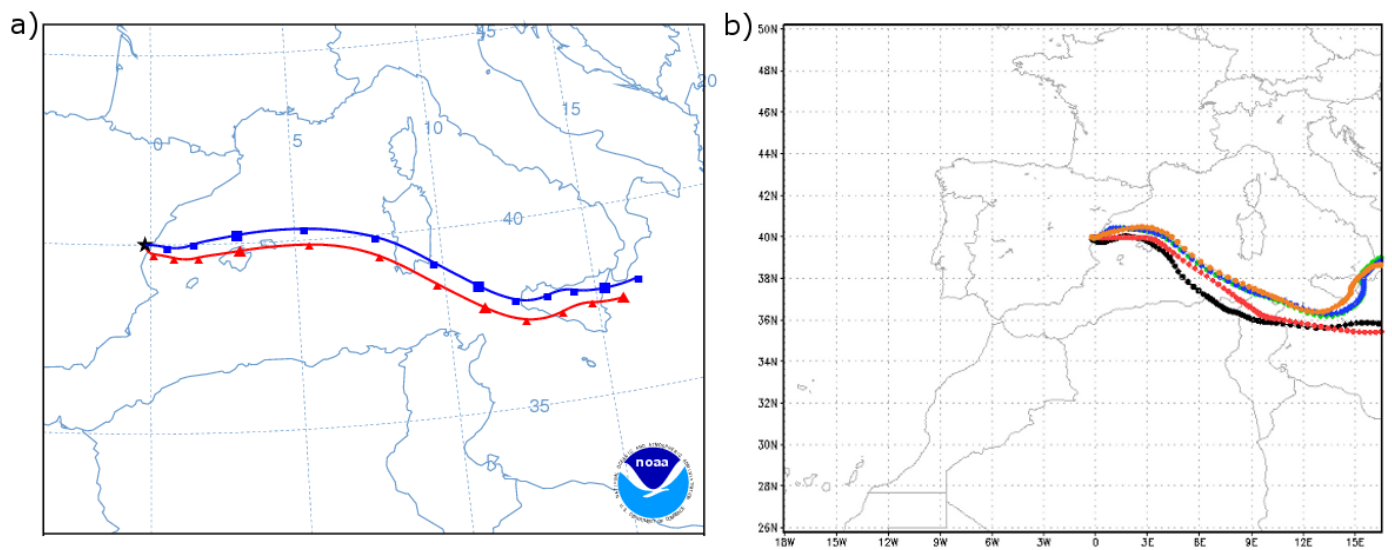

Figure 7. Backward trajectories ending in the rain area $\left(40.0,0.2^{\circ} \mathrm{W}\right.$ ) for the October 2000 event. (a) $72 \mathrm{~h}$ trajectories (source: NOAA Air Resources Laboratory) ending at $100 \mathrm{~m}$ a.g.l. at 18:00 UTC, 25 October (blue) and 00:00 UTC, 26 October (red), (b) trajectories ending at 00:00 UTC, 7 September (source: RAMS model, CtrlB: black, B1: red, B2: green, B3: blue, B0: orange).

The latter modelled rain event, October 2007, presents similarities regarding recorded precipitation spatial distribution with the one from September 1989. Rainfall was located in the area with highest torrentiality in the Valencia region and model results show roughly the same spatial distribution although the 2007 case has a lower spatial extent. Control simulation (Fig. 13a) shows a maximum precipitation accumulated value (above $240 \mathrm{~mm}$ ) located on the centre of the 

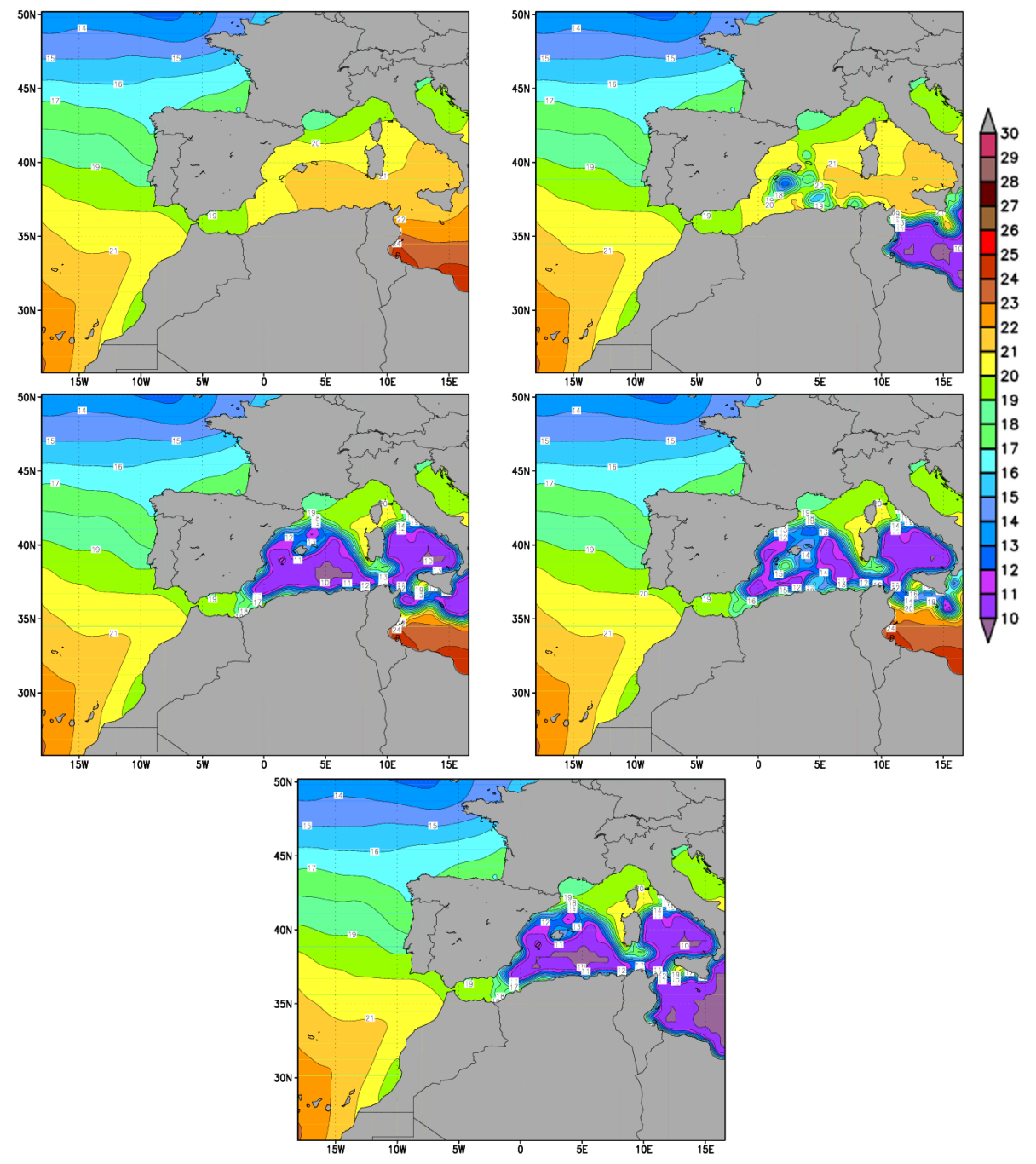

Figure 8. As Fig. 4 for October 2000 event: (a) control run, (b) B1, (c) B2, (d) B3 and (e) B0.

model grid, some distance inland, with a secondary maximum area over the sea with a clearly lower value. A relatively large area with precipitation values exceeding $100 \mathrm{~mm}$ lays around the first cited maximum area.

The first simulation with perturbed SST, C1 (Fig. 13b), shows a notable decrease of about $100 \mathrm{~mm}$ in the maximum accumulated values. Concerning spatial distribution, rainfall structure over land present the same features as in control simulation; the main differences appear over the sea where the secondary maximum located over the sea in control simulation completely disappears in this case while a larger rain band appears to the south of the model grid. The simulation results for $\mathrm{C} 2$ (Fig. 13c) and $\mathrm{CO}$ (Fig. 13d) experiments present quite similar results. Both simulations show a dramatic decrease on model-accumulated precipitation that disappears over most of the model grid, only some residual precipitation is found inland far away from the control simulation precipitation area.
As in the previous experiments, air mass trajectories (Fig. 11b) and vertical cross section (see Supplement) of equivalent potential temperature plus vertical velocity from RAMS model results have been analysed. Air mass advection from northern Mediterranean brought marine air at surface levels towards the Valencia region. For the control and $\mathrm{C} 1$ simulations, clear surface moisture flux from the Mediterranean to the precipitation area is found while some differences appear in the location and intensity of vertical ascent. Again, $\mathrm{C} 2$ and $\mathrm{CO}$ simulations show very similar results with a drastic decline of surface moisture flux towards the coast, leading to reduced precipitation.

\section{Conclusions}

A study has been conducted to determine the influence of SST in the results of numerical modelling of torrential rain events. For this purpose, three different torrential rain events 

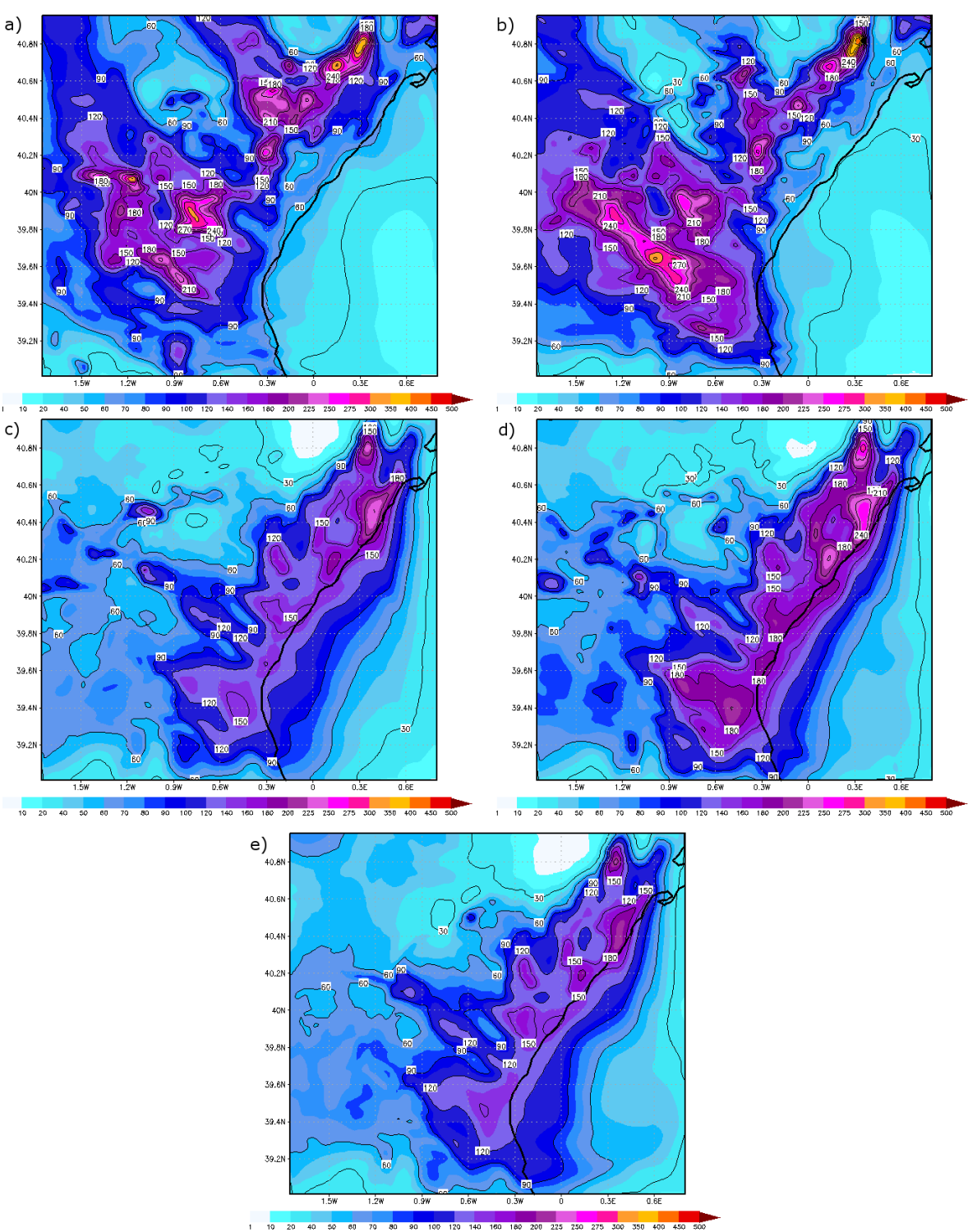

Figure 9. RAMS model accumulated precipitation (mm) for October 2000 event for (a) CtrlB simulation, (b) B1, (c) B2, (d) B3 and (e) B0.

in the Valencia region, eastern Spain, have been studied with the Regional Atmospheric Modelling System (RAMS). Unlike other authors who tried to elucidate SST role in numerical simulations by uniformly modifying the SST field in the study area, the authors have adopted a different approach. Instead of disturbing the entire SST field or only the marine areas closest to the rain area, we perturbed SST only over the sea areas that most probably could play a role in the development of the rain episode. Main conclusions of the subsequent simulation experiments are discussed in this section.

In a previous work (Pastor, 2012) SST field in the Mediterranean was analysed from satellite data. The development of an SST climatology determined its spatial distribution across the year, finding two main distribution modes in winter and summer and transitional periods, spring and autumn, be- tween them; these SST regimes do not strictly coincide with climatological seasons. In both modes (winter and summer), different areas presenting similar qualitative features, regarding spatial extent and SST values, were found throughout the whole study period. This information has been used in this paper to perturb SST field according to those areas so its influence in the model simulation of the rain event could be investigated. A more extensive discussion of SST spatial distribution regime in the Mediterranean can be found in Sect. 2.1, sea surface temperature data.

For each event air mass trajectories have been studied to determine the Mediterranean areas in which air-sea exchange that affects precipitation amount and distribution could take place. Then, a value of $10^{\circ} \mathrm{C}$ was prescribed for each area the air mass travelled above assuming no heat/moisture air-sea 

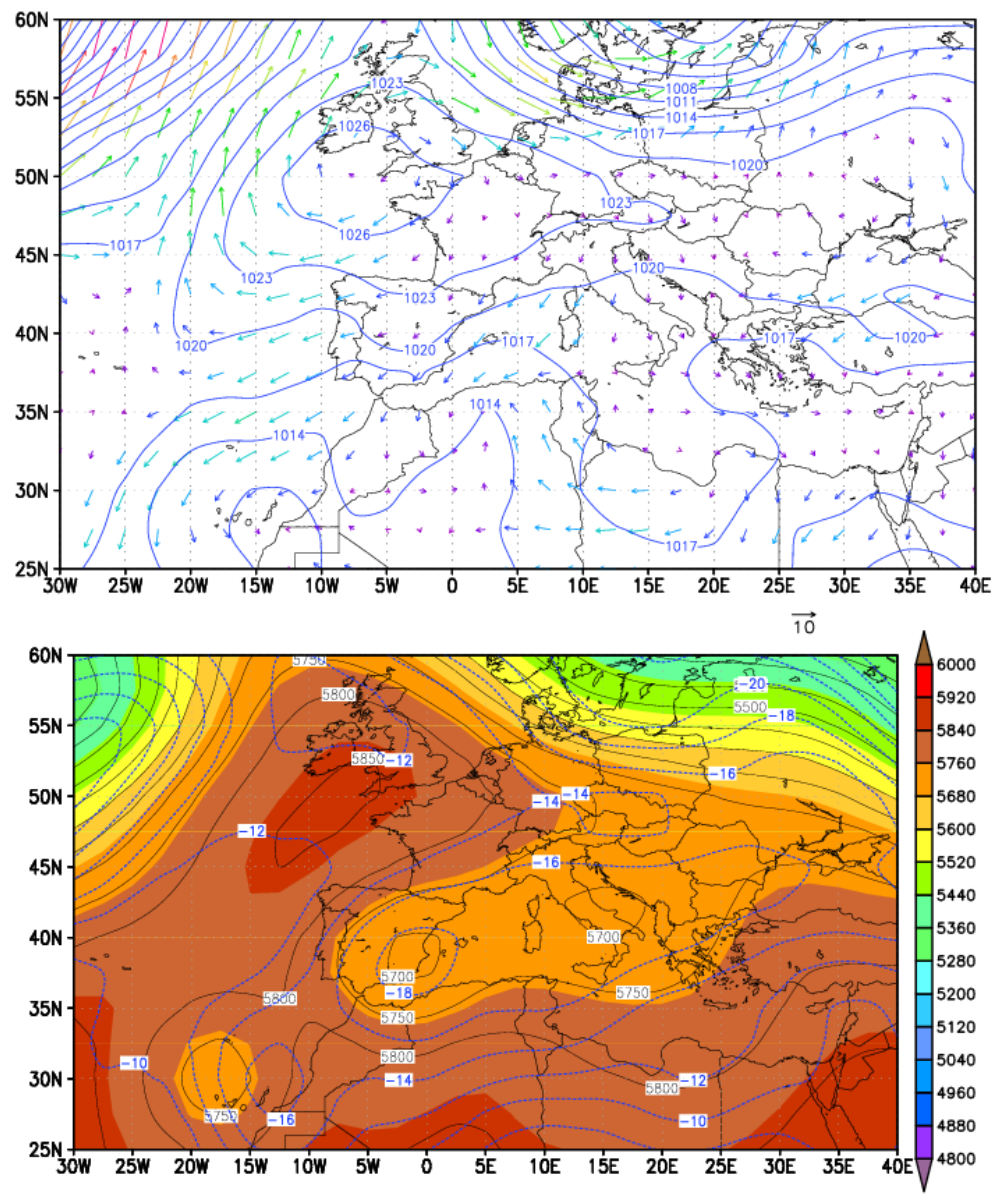

Figure 10. Synoptic situation on 12 October 2007, 00:00 UTC; (a) sea surface pressure and winds at surface level; (b) geopotential height $(\mathrm{gpm})$ and temperature at $500 \mathrm{hPa}$. Plotted from NCEP model data.

exchanges are present or are almost inhibited for this SST. With the new SST fields, as many simulations as perturbed SST areas were defined have been run. Results of the different modelling experiments have been compared against a control simulation with original unperturbed SST data.

Summarizing model-accumulated precipitation results from all simulations (Figs. 5, 9 and 13) it stands out that SST plays an important role in the development and/or intensification of torrential rain events in the Valencia region. At a greater or lesser extent, remarkable changes have been found on both the spatial distribution and/or accumulated precipitation. Depending on the modified SST area, main changes on the simulation results affect spatial distribution or total amount of precipitation calculated by the model.

For the summer and winter SST regime events, September 1989 and October 2007 respectively, the modified SST simulation experiments that resemble more the control simulation are the ones in which the areas with higher SST are preserved and the modified areas are the coldest in the air mass trajectory. On the contrary, modifying areas closest to the Valencia region or the ones with highest SST led to a notable or even drastic decline in precipitation totals. For these events, the most important change has been in the total rainfall amount calculated by the model, usually decreasing values in a greater or lesser degree. Spatial precipitation distribution, although with some changes, showed a similar structure and/or location in most cases. In the event of October 2000 the simulation with less change with respect to the control simulation in both spatial distribution and rainfall amounts is the one where the most remote area across the air mass trajectory (Gulf of Tunis and Libyan coast) modifies its SST, and is also the one with highest SST values. In the rest of the cases the main effect has been a change in model rainfall spatial distribution. Contrasting with the other two events, in October 2000, with SST autumn transitional regime, a change occurred in the spatial distribution of the precipitation by moving the precipitation field to the east but still retaining the rain band spatial structure. Changes in total accumulated precipitation were not as important as in the case of the two other events but still significant for some of the simulations. 

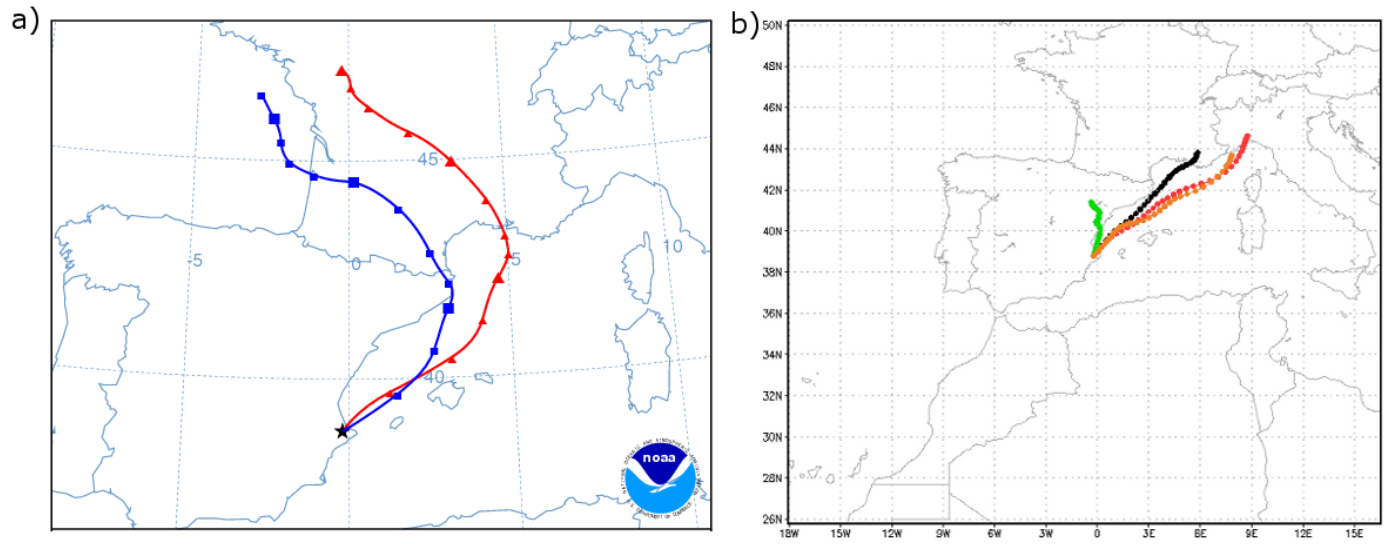

Figure 11. Backward trajectories ending in the rain area $\left(38.8,0.2^{\circ} \mathrm{W}\right)$ for the October 2007 event. (a) $72 \mathrm{~h}$ trajectories (source: NOAA Air Resources Laboratory) ending at $100 \mathrm{~m}$ a.g.l. at 18:00 UTC, 11 October (blue) and 00:00 UTC, 12 October (red), (b) trajectories ending at 00:00 UTC, 12 October (source: RAMS model; CtrlC: black, C1: red, C2: green, C0: orange).
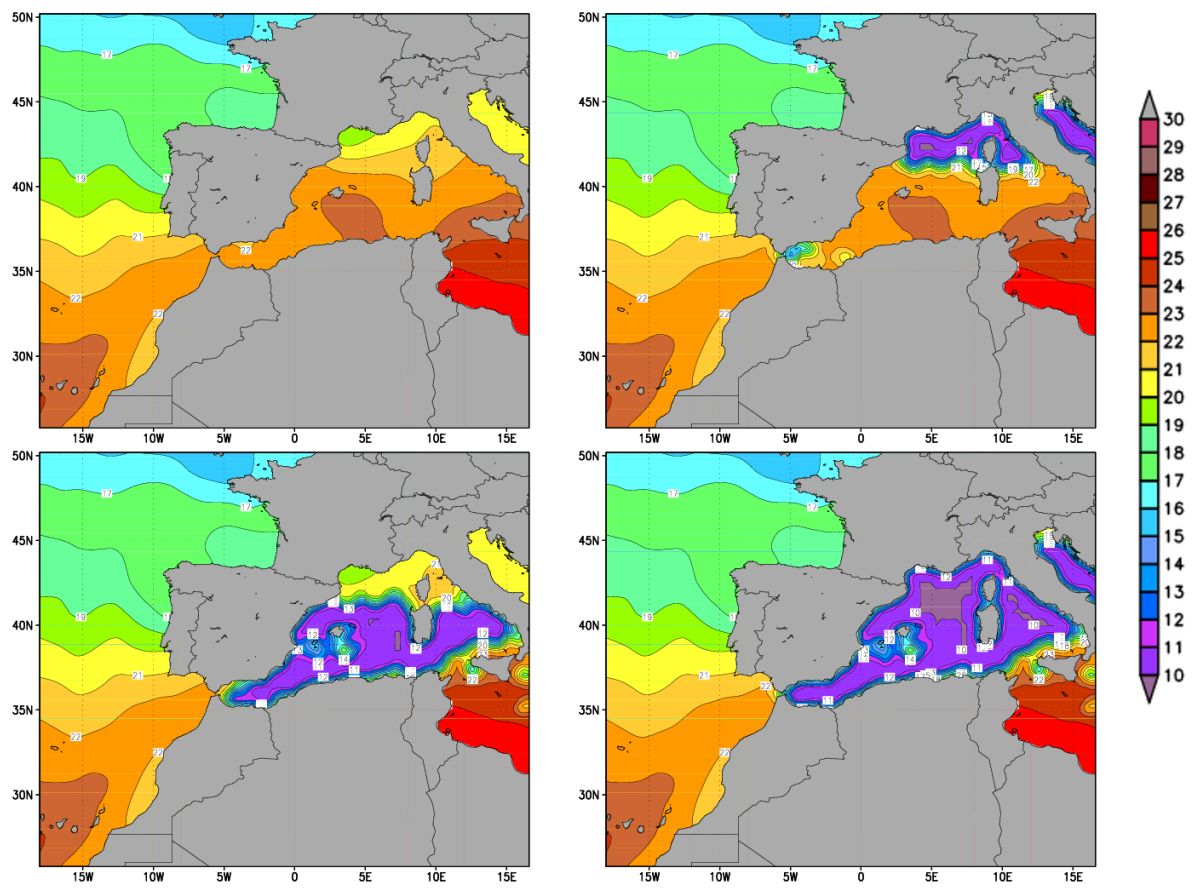

Figure 12. As Fig. 4 for October 2007 event: (a) control run, (b) C1, (c) C2 and (d) C3.

The attribution of changes in the model results should be handled with caution. Additionally to the effect of the modification on the heat/moisture exchanges between the air mass and the sea because of the perturbation of initial SST fields, it must be taken into account the possibility that these perturbations could affect the dynamics of the atmosphere. Air mass trajectories computed from RAMS model control simulations are quite similar to those computed from reanalysis data. Mostly, trajectories for the RAMS SST perturbed simulations do not show noticeable changes with respect to the control simulation one despite the perturbation of the SST field. Hence, we can conclude that the perturbation of SST field did not produce appreciable changes in atmospheric dynamics. Consequently, we can attribute most of, though not entirely, the changes in the model results to the SST field modification.

For the Valencia region, taking into account the RAMS model results, the area with the greatest influence on model precipitation results is the one comprised between the Valencia coast and the Balearic Islands. To a lesser extent, other areas with a notable contribution to simulated rainfall are south of the Tyrrhenian Sea, the Gulf of Tunis and the central sector of the Western Mediterranean between the Balearic Islands and Corsica-Sardinia. In these latter cases, their contri- 

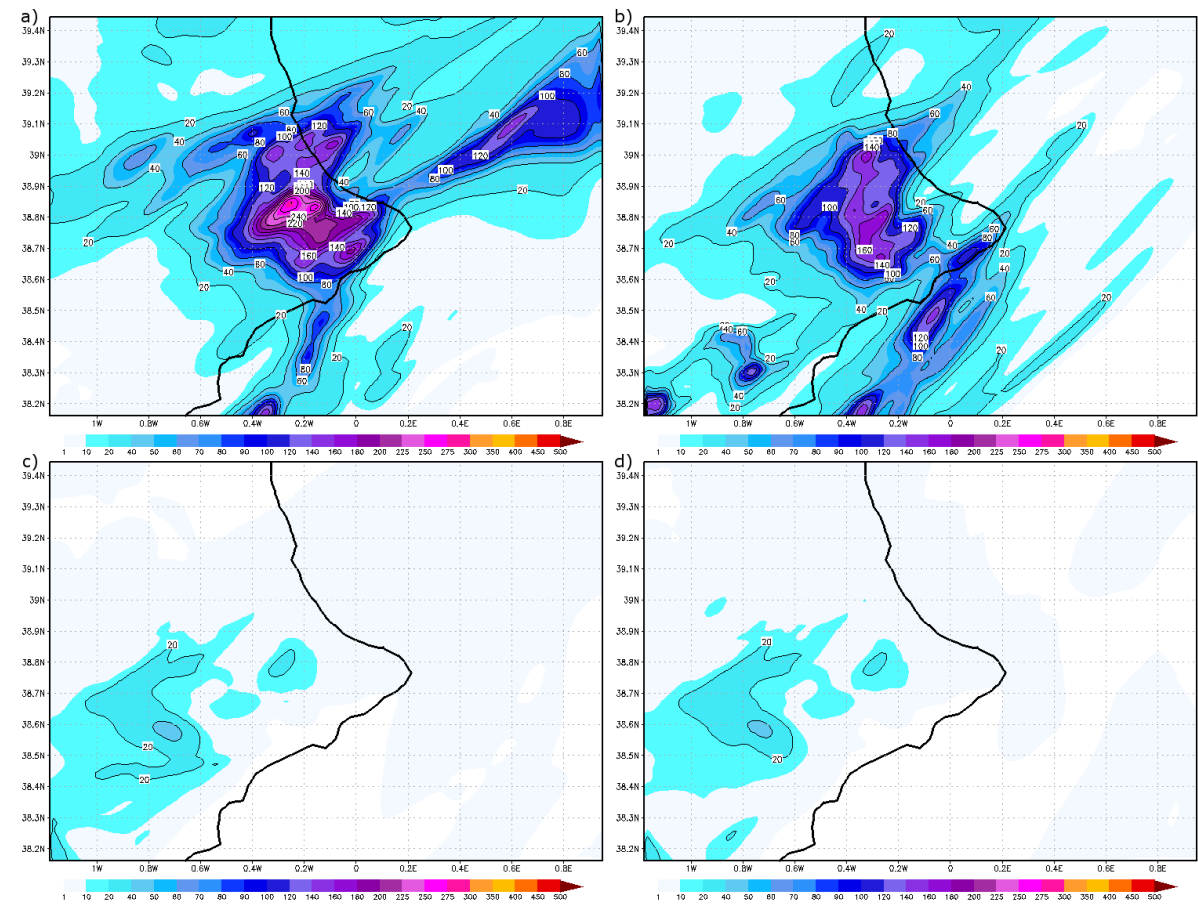

Figure 13. RAMS model accumulated precipitation (mm) for October 2007 event for (a) CtrlC simulation, (b) C1, (c) C2 and (d) C0.

bution is most important when the air mass crosses the Western Mediterranean across its path to the Valencia region. It should be noted that in the case of the Gulf of Tunis a part of the contribution could be attributed to the coastal areas of Algeria. We have also found that SST in the northern parts of the Western Mediterranean and the Straits of Gibraltar have little influence on the development of heavy rainfall in the Valencia region during the studied episodes.

The simulation strategy developed in this paper could or should be used to simulate more torrential rain episodes in other areas of the Mediterranean basin to look for potential destabilization of air masses that can lead to such rain events. The determination of sea areas that contribute to the development or intensification of heavy rain events in the Mediterranean countries could be used as a prognosis and monitoring tool by monitoring SST anomalies and/or values in such areas; although attention should also be paid to other factors, such as the synoptic situation, since the mere presence of high SST values does not in itself guarantee the occurrence of torrential rains.

The Supplement related to this article is available online at doi:10.5194/nhess-15-1677-2015-supplement.
Acknowledgements. F. Pastor would like to thank B. Codina for his invaluable help with his doctoral thesis and Jose Luis Palau for his critical review on this paper. This work was funded by the Spanish Ministerio de Economía y Competitividad projects CGL2008-04550/CLI (NIEVA), CSD2007-00067 CONSOLIDERINGENIO 2010 (GRACCIE), CTM2014-59111-REDC (RED GRACCIE), CGL2011-30433-C02 (TERMED) and CGL201017623 (MODELISMOS), the Generalitat Valenciana funded project PROMETEOII/2014/038 (DESESTRES) and the EUfunded Integrated Project CIRCE (Project No. 036961). The AVHRR Oceans Pathfinder SST data were obtained from the Physical Oceanography Distributed Active Archive Center (PO.DAAC) at the NASA Jet Propulsion Laboratory, Pasadena, CA. (http://podaac.jpl.nasa.gov). Reanalysis data for this study are from the Research Data Archive (RDA) which is maintained by the Computational and Information Systems Laboratory (CISL) at the National Center for Atmospheric Research (NCAR). NCAR is sponsored by the National Science Foundation (NSF). The original data are available from the RDA (http://dss.ucar.edu) in data set number ds090.0. The authors gratefully acknowledge the NOAA Air Resources Laboratory (ARL) for the provision of the HYSPLIT transport and dispersion model and/or READY website (http://www.ready.noaa.gov) used in this publication. The CEAM Foundation is supported by the Generalitat Valenciana.

Edited by: M.-C. Llasat

Reviewed by: two anonymous referees 


\section{References}

Anderson, J. R., Hardy, E. E., Roach, J. T., and Witmer, R. E.: A land use and land cover classification system for use with remote sensor data, Tech. rep., US Geological Survey Professional Paper 964, Government Printing Office, Washington, D.C., 1976.

Barredo, J. I.: Normalised flood losses in Europe: 1970-2006, Nat. Hazards Earth Syst. Sci., 9, 97-104, doi:10.5194/nhess-9-972009, 2009.

Bethoux, J., Gentili, B., Morin, P., Nicolas, E., Pierre, C., and RuizPino, D.: The Mediterranean Sea: a miniature ocean for climatic and environmental studies and a key for the climatic functioning of the North Atlantic, Prog. Oceanogr., 44, 131-146, 1999.

Bozkurt, D. and Sen, O.: Precipitation in the Anatolian Peninsula: sensitivity to increased SSTs in the surrounding seas, Clim. Dynam., 36, 711-726, 2009.

Bresson, R., Ricard, D., and Ducrocq, V.: Idealized mesoscale numerical study of Mediterranean heavy precipitating convective systems, Meteorol.Atmos. Phys., 103, 45-55, 2009.

Campins, J., Genovés, A., Picornell, M., and Jansà, A.: Climatology of Mediterranean cyclones using the ERA-40 dataset, Int. J. Climatol., 31, 1596-1614, doi:10.1002/joc.2183, 2011.

Cohuet, J., Romero, R., Homar, V., Ducrocq, V., and Ramis, C.: Initiation of a severe thunderstorm over the Mediterranean Sea, Atmos. Res., 100, 603-620, 2011.

D'Ortenzio, F., Marullo, S., and Santoleri, R.: Validation of AVHRR Pathfinder SST's over the Mediterranean sea, Geophys. Res. Lett., 27, 241-244, 2000.

Ducrocq, V., Nuissier, O., Ricard, D., Lebeaupin, C., and Thouvenin, T.: A numerical study of three catastrophic precipitating events over southern France, II: Mesoscale triggering and stationarity factors, Q. J. Roy. Meteorol. Soc., 134, 131-145, 2008.

Duffourg, F. and Ducrocq, V.: Origin of the moisture feeding the Heavy Precipitating Systems over Southeastern France, Nat. Hazards Earth Syst. Sci., 11, 1163-1178, doi:10.5194/nhess-111163-2011, 2011.

EEA - European Environment Agency: Mapping the impacts of natural hazards and technological accidents in Europe An overview of the last decade, Technical report No. 132010, doi:10.2800/62638, Copenhagen, 2010.

Estrela, M., Pastor, F., and Millán, M.: Air Mass Change along Trajectories in the Western Mediterranean Basin in the Torrential Rain Events in the Valencia Region, in: Proceedings, 4th EGS Plinius Conference on Mediterranean Storms, edited by: Jansà, A. and Romero, R., October 2002, Mallorca, 2003.

Estrela, M., Pastor, F., and Gómez, I.: Meteorological Risk Factors and Torrential Precipitation in the Spanish Mediterranean Coast, in: Adverse Weather in Spain, edited by: García-Legaz, C. and Valero, F., WCRP Spanish Committee, Madrid, 108-120, 2013.

Federico, S., Avolio, E., Bellecci, C., Lavagnini, A., Colacino, M., and Walko, R. L.: Numerical analysis of an intense rainstorm occurred in southern Italy, Nat. Hazards Earth Syst. Sci., 8, 1935, doi:10.5194/nhess-8-19-2008, 2008.

Fernández, C., Gaertner, M., Gallardo, C., and Castro, M.: Simulation of a long-lived meso-beta scale convective system over the Mediterranean coast of spain, part ii: Sensitivity to external forcings, Meteorol. Atmos. Phys., 62, 179-200, 1997.

García Codron, J. C., Diego Liaño, C., Fdez. de Arróyabe Hernáez, P., Garmendia Pedraja, C., and Rasilla Álvarez, D. (Eds.): El Clima entre el Mar y la Montaña, Asociación Española de Cli- matología y Universidad de Cantabria, Serie A, no. 4, Santander, 2004.

Gómez, I., Pastor, F., and Estrela, M. J.: Sensitivity of a mesoscale model to different convective parameterization schemes in a heavy rain event, Nat. Hazards Earth Syst. Sci., 11, 343-357, doi:10.5194/nhess-11-343-2011, 2011.

Gómez, I., Caselles, V., and Estrela, M.: Real-time weather forecasting in the Western Mediterranean Basin: An application of the RAMS model, Atmos. Res., 139, 71-89, 2014.

Homar, V., Romero, R., Ramis, C., and Alonso, S.: Numerical study of the October 2000 torrential precipitation event over eastern Spain: analysis of the synoptic-scale stationarity, Ann. Geophys., 20, 2047-2066, doi:10.5194/angeo-20-2047-2002, 2002.

Homar, V., Jansà, A., Campins, J., Genovés, A., and Ramis, C.: Towards a systematic climatology of sensitivities of Mediterranean high impact weather: a contribution based on intense cyclones, Nat. Hazards Earth Syst. Sci., 7, 445-454, doi:10.5194/nhess-7445-2007, 2007.

Jansà, A., Genovès, A., and Garcìa-Moya, J. A.: Western Mediterranean cyclones and heavy rain, Part 1: Numerical experiment concerning the Piedmont flood case, Meteorol. Appl., 7, 323 333, doi:10.1017/S1350482700001663, 2000.

Jansà, A., Genovès, A., Picornell, M. A., Campins, J., Riosalido, R., and Carretero, O.: Western Mediterranean cyclones and heavy rain, Part 2: Statistical approach, Meteorol. Appl., 8, 43-56, 2001.

Jansa, A., Alpert, P., Arbogast, P., Buzzi, A., Ivancan-Picek, B., Kotroni, V., Llasat, M. C., Ramis, C., Richard, E., Romero, R., and Speranza, A.: MEDEX: a general overview, Nat. Hazards Earth Syst. Sci., 14, 1965-1984, doi:10.5194/nhess-14-19652014, 2014.

Kallos, G., Kotroni, V., Lagouvardos, K., and Papadopoulos, a.: On the Long-Range transport of air pollutants from Europe to Africa, Geophys. Res. Lett., 25, 619-622, 1998.

Kalnay, E., Kanamitsu, M., Kistler, R., Collins, W., Deaven, D., Gandin. L., Iredell, M., Saha, S., White, G., Woolen, J., Zhu, Y., Chelliah, M., Ebisuzaki, W., Higgins, W., Janowiak, J., Mo, K. C., Ropelewski, C., Wnag, J., Leetmaa, A., Reynolds, R., Jenne, R., Joseph, D.: The NCEP/NCAR 40-Year Reanalysis Project, B Am. Meteorol. Soc., 77, 437-471, 1996.

Katsafados, P., Mavromatidis, E., Papadopoulos, A., and Pytharoulis, I.: Numerical simulation of a deep Mediterranean storm and its sensitivity on sea surface temperature, Nat. Hazards Earth Syst. Sci., 11, 1233-1246, doi:10.5194/nhess-111233-2011, 2011.

Kilpatrick, K., Podestá, G., and Evans, R.: Overview of the NOAA/NASA advanced very high resolution radiometer Pathfinder algorithm for sea surface temperature and associated matchup database, J. Geophys. Res.-Oceans, 106, 9179-9197, 2001.

Kouroutzoglou, J., Flocas, H. A., Keay, K., Simmonds, I., and Hatzaki, M.: Climatological aspects of explosive cyclones in the Mediterranean, Int. J. Climatol., 31, 1785-1802, 2011.

Lebeaupin, C., Ducrocq, V., and Giordani, H.: Sensitivity of torrential rain events to the sea surface temperature based on highresolution numerical forecasts, J. Geophys. Res.-Atmos., 111, 12110-12110, 2006.

Lenderink, G., Meijgaard, E., and Selten, F.: Intense coastal rainfall in the Netherlands in response to high sea surface temperatures: 
analysis of the event of August 2006 from the perspective of a changing climate, Clim. Dynam., 32, 19-33, 2008.

Lionello, P.: Cyclones in the Mediterranean Region: Climatology and Effects on the Environment, in: Chapter 6, Developments in Earth and Environmental Sciences, Vol. 4, edited by: Lionello, P., Malanotte-Rizzoli, P., and Boscolo, R., Mediterranean, 1-421, 2006.

Martín, A., Romero, R., De Luque, A., Alonso, S., Rigo, T., and Llasat, M.: Sensitivities of a Flash Flood Event over Catalonia: A Numerical Analysis, Mon. Weather Rev., 135, 651-669, 2007.

Marullo, S., Buongiorno Nardelli, B., Guarracino, M., and Santoleri, R.: Observing the Mediterranean Sea from space: 21 years of Pathfinder-AVHRR sea surface temperatures (1985 to 2005): reanalysis and validation, Ocean Sci., 3, 299-310, doi:10.5194/os3-299-2007, 2007.

Meneguzzo, F., Pasqui, M., Menduni, G., Messeri, G., Gozzini, B., Grifoni, D., Rossi, M., and Maracchi, G.: Sensitivity of meteorological high-resolution numerical simulations of the biggest floods occurred over the Arno river basin, Italy, in the 20th century, J. Hydrol., 288, 37-56, 2004.

Miglietta, M., Moscatello, A., Conte, D., Mannarini, G., Lacorata, G., and Rotunno, R.: Numerical analysis of a Mediterranean 'hurricane' over south-eastern Italy: Sensitivity experiments to sea surface temperature, Atmos. Res., 101, 412-426, 2011.

Millán, M., Estrela, M., and Caselles, V.: Torrential precipitations on the Spanish east coast: the role of the Mediterranean sea surface temperature, Atmos. Res., 36, 1-16, 1995.

Millán, M., Estrela, M., and Miró, J.: Rainfall components: variability and spatial distribution in a Mediterranean Area (Valencia Region), J. Climate, 18, 2682-2705, 2005a.

Millán, M., Estrela, M., Sanz, M., Mantilla, E., Martín, M., Pastor, F., Salvador, R., Vallejo, R., Alonso, L., Gangoiti, G., Ilardia, J. L., Navazo, M., Albizuri, A., Artíñano, B., Ciccioli, P., Kallos, G., Carvalho, R. A., Andrés, D., Hoff, A., Werhahn, J., Seufert, G., and Versino, B.: Climatic Feedbacks and Desertification: The Mediterranean Model, J. Climate, 18, 684-701, 2005b.

Moscatello, A., Miglietta, M., and Rotunno, R.: Numerical Analysis of a Mediterranean "Hurricane" over Southeastern Italy, Mon. Weather Rev., 136, 4373-4397, doi:10.1175/2008MWR2512.1, 2008.

Navarra, A. and Tubiana, L. (Eds.): Regional Assessment of the Climate Change in the Mediterranean: Air, Sea and Precipitation and Water, Springer Verlag, Dordrecht, the Netherlands, 2013.

Palau, J. and Rovira, F.: Meso-alpha scale tropospheric interactions within the Western Mediterranean Basin : Statistical results using 15-year NCEP/NCAR reanalysis dataset, Adv. Meteorol., Hindawi Publishing Corporation Advances in Meteorology, Vol. 2015, http://dx.doi.org/10.1155/2015/302746 (last access: July 2015), 2014.

Palau, J. L., Pérez-Landa, G., Diéguez, J. J., Monter, C., and Millán, M. M.: The importance of meteorological scales to forecast air pollution scenarios on coastal complex terrain, Atmos. Chem. Phys., 5, 2771-2785, doi:10.5194/acp-5-2771-2005, 2005.

Pastor, F.: Ciclogénesis intensas en la cuenca occidental del Mediterráneo y temperatura superficial del mar: Modelización y evaluación de las áreas de recarga, Doctoral thesis, Universitat de Barcelona, Barcelona, 2012.
Pastor, F., Estrela, M., Peñarrocha, D., and Millán, M.: Torrential Rains on the Spanish Mediterranean Coast: Modeling the Effects of the Sea Surface Temperature, J. Appl. Meteorol., 40, 11801195, 2001.

Pastor, F., Estrela, M., Miró, J., Gómez, I., Valiente, J., and Niclòs, R.: Torrential rains: Using satellite-retrieved sea surface temperature as a forecast input data, in: Effects of Climate Change on the World's Oceans, vol. 2010, International Symposium, Gijón, Spain, 2008.

Pastor, F., Gómez, I., and Estrela, M. J.: Numerical study of the October 2007 flash flood in the Valencia region (Eastern Spain): the role of orography, Nat. Hazards Earth Syst. Sci., 10, 13311345, doi:10.5194/nhess-10-1331-2010, 2010.

Peñarrocha, D., Estrela, M., and Millán, M.: Classification of daily rainfall patterns in a Mediterranean area with extreme intensity levels: the Valencia region, Int. J. Climatol., 22, 677-695, 2002.

Pérez-Landa, G., Ciais, P., Gangoiti, G., Palau, J. L., Carrara, A., Gioli, B., Miglietta, F., Schumacher, M., Millán, M. M., and Sanz, M. J.: Mesoscale circulations over complex terrain in the Valencia coastal region, Spain - Part 2: Modeling $\mathrm{CO}_{2}$ transport using idealized surface fluxes, Atmos. Chem. Phys., 7, 1851-1868, doi:10.5194/acp-7-1851-2007, 2007a.

Pérez-Landa, G., Ciais, P., Sanz, M. J., Gioli, B., Miglietta, F., Palau, J. L., Gangoiti, G., and Millán, M. M.: Mesoscale circulations over complex terrain in the Valencia coastal region, Spain Part 1: Simulation of diurnal circulation regimes, Atmos. Chem. Phys., 7, 1835-1849, doi:10.5194/acp-7-1835-2007, 2007b.

Pielke, R., Cotton, W., Walko, R., Tremback, C., Lyons, W., Grasso, L., Nicholls, M., Moran, M., Wesley, D., Lee, T. J., and Copeland, J.: A Comprehensive Meteorological Modeling System - \{RAMS $\}$, Meteorol. Atmos. Phys., 49, 69-91, 1992.

Rainaud, R., Brossier, C. L., Ducrocq, V., Giordani, H., Nuret, M., Fourrié, N., Bouin, M.-N., Taupier-Letage, I., and Legain, D.: Characterization of air-sea exchanges over the Western Mediterranean Sea during HyMeX SOP1 using the AROME-WMED mode, Q. J. Roy. Meteorol. Soc., doi:10.1002/qj.2480, in press, 2015.

Robinson, A., Leslie, W. G., Theocharis, A., and Lascaratos, A.: Mediterranean Sea circulation, in: Encyclopedia of Ocean Sciences, Academic Press, San Diego, 1689-1706, 2001.

Romero, R.: Sensitivity of a heavy rain producing western Mediterranean cyclone to embedded potential vorticity anomalies, Q. J. Roy. Meteorol. Soc., 127, 2559-2597, 2001.

Romero, R., Ramis, C., and Homar, V.: On the severe convective storm of 29 October 2013 in the Balearic Islands: observational and numerical study, Q. J. Roy. Meteorol. Soc., 141, 1208-1222, doi:10.1002/qj.2429, 2014.

Salvador, R., Calbó, J., and Millán, M.: Horizontal grid size selection and its influence on mesoscale model simulations, J. Appl. Meteorol., 39, 1311-1329, 1999.

Tous, M., Romero, R., and Ramis, C.: Surface heat fluxes influence on medicane trajectories and intensification, Atmos. Res., 123, 400-411, 2013.

Walko, R., Cotton, W., and Meyers, M.: New RAMS cloud microphysics parameterization part I: the single-moment scheme, Atmos. Res., 38, 29-62, 1995. 